\title{
Comparative anti-inflammatory and antinociceptive effects of terpenoids and an aqueous extract obtained from Croton cajucara Benth
}

\author{
Fabio F. Perazzo', José Carlos T. Carvalho', Marcelo Rodrigues', \\ Ellen Kadja L. Morais ${ }^{3}$, Maria Aparecida M. Maciel ${ }^{3 *}$ \\ ${ }^{1}$ Laboratório de Pesquisa em Fármacos, Centro de Ciências Biológicas e da Saúde, Universidade Federal do \\ Amapá, Rod. JK, km 02, 68902-303, Macapá, AP, Brazil, \\ ${ }^{2}$ Laboratório de Farmacologia e Toxicologia de Produtos Naturais, Departamento de Farmacologia, Instituto de \\ Ciências Biomédicas, USP, São Paulo, Brazil, \\ ${ }^{3}$ Universidade Federal do Rio Grande do Norte, Departamento de Química, \\ Campus Universitário, 59072-970, Natal, RN, Brazil
}

\begin{abstract}
RESUMO: "Avaliação comparativa dos efeitos anti-inflamatório e antinociceptivo de terpenóides e de extrato aquoso obtidos de Croton cajucara Benth". O 19-nor-clerodano trans-crotonina (CTN) e o triterpeno ácido acetil aleuritólico (AAA), isolados das cascas do caule de Croton cajucara Benth (Euphorbiaceae), uma planta tradicional da Região Amazônica do Brasil, bem como o extrato aquoso (EA) das cascas do caule deste Croton, foram submetidos a experimentos farmacológicos utilizando animais, para avaliação das atividades anti-inflamatória e antinociceptiva. A administração oral de AAA (50 mg/kg), CTN $(50 \mathrm{mg} / \mathrm{kg})$ ou AE $(300 \mathrm{mg} /$ $\mathrm{kg}$ ) inibiram as contorções em ratos, induzidas por ácido acético. Os terpenóides AAA e CTN, bem como o extrato polar EA, inibiram significativamente o edema de pata em ratos, induzido por carragenina. As inibições foram observadas em todos os intervalos de medições, tendo sido evidenciado melhores inibições para os terpenóides AAA $(47,7 \%$, após a primeira hora) e CTN (54,4\%, após a segunda hora). Evidenciou-se ainda, após 90 minutos do estímulo, significante inibição no edema induzido por dextrana $(31,9 \%$ para CTN e $28,5 \%$ para AAA) e por histamina (43,2\% para CTN e 40,5\% para AAA). Estes resultados confirmam o uso popular de Croton cajucara na região Amazônica do Brasil, no combate a inflamações.
\end{abstract}

Unitermos: Croton cajucara, ácido acetil aleuritólico, trans-crotonina, anti-inflamatório, antinociceptivo.

\begin{abstract}
The 19-nor-clerodane trans-crotonin (CTN) and the triterpene acetyl aleuritolic acid (AAA), isolated from the stem bark of Croton cajucara Benth (Euphorbiaceae), a traditional medicinal plant from Amazon region of Brazil, as well as the aqueous extract (AE) from its stem bark, were submitted to pharmacological screening for anti-inflammatory and antinociceptive activities in animal models. The oral administration of AAA $(50 \mathrm{mg} / \mathrm{kg})$, CTN $(50 \mathrm{mg} / \mathrm{kg})$ or $\mathrm{AE}(300 \mathrm{mg} / \mathrm{kg})$ inhibited the acetic acid-induced writhing in mice. The AE, CTN and AAA had shown significant inhibition of carrageenin-induced edema in rats, in all time intervals measured after the injection of the stimulus, with the greatest inhibition at the first hour for AAA $(47.7 \%)$ and the second hour for CTN (54.4\%). They have also exhibited significant inhibition in the dextran-induced edema 90 minutes after the stimulus: $31.9 \%$ for CTN and $28.5 \%$ for AAA. In the histamine-induced edema, the inhibition showed by CTN and AAA were $43.2 \%$ and $40.5 \%$, respectively, 90 minutes after the injection of stimulus. This study extends and supports the popular medicine and folkloric uses of Croton cajucara in the Amazon region of Brazil.
\end{abstract}

Keywords: Croton cajucara, acetyl aleuritolic acid, trans-crotonin, anti-inflammatory, antinociceptive.

\section{INTRODUCTION}

Croton cajucara Benth (Euphorbiaceae) has been a very important traditional medicine in Brazil. It occurs widely in the Amazon rainforest region (Brazil) where is popularly known as 'sacaca', which means witchery in Tupi-Guarani indigenous language. The stem bark of this plant is used for primary health care to treat liver and kidney disorders (Di Stasi et al., 1989; Martins, 1989; Farias et al., 1996). In addition, the water extract from the stem bark is also used to treat diabetes, diarrhea, stomachache, fever, jaundice, hepatitis, malaria and also to lower blood cholesterol (Van Den Berg, 1993; Di Stasi et al., 1994; Barbosa-Filho et al., 2005). The 
use of leaves to overcome weigh has been encouraged in the Amazon region of Brazil, however, toxic hepatitis frequently appears as a side effect (Maciel et al., 2000). This observation may be correlated with the chronic use required for losing weigh, since a lack of acute toxicity has been described and this toxicological effect was not noticed (Farias et al., 1996).

The stem bark of this specie is a rich source of clerodane-type diterpenes (Maciel et al., 1998a,b, 2000, 2003; Souza et al., 2006) and our previously pharmacological studies performed with the isolated terpenoids trans-dehydrocrotonin (DCTN), transcrotonin (CTN) and acetyl aleuritolic acid (AAA) (Figure 1) proved striking correlation among these compounds with the folk traditional therapeutic uses of Croton cajucara, being DCTN the leading compound (Maciel et al., 2000; Costa et al., 2007). Specifically, DCTN showed antioestrogenic (Luna-Costa, 1999), anti-inflammatory and antinociceptive (Carvalho et al., 1996) effects, and has also demonstrated hypoglycemic (Farias et al., 1997), antiatherogenic and hypolipidaemic activities (Silva et al., 2001). Additionally, an anticancer effect had also been described (Grynberg et al., 1999).

The biological importance of natural and semisynthetic CTN has been reported (Grynberg et al., 1999; Maciel et al., 2000; Hiruma-Lima et al., 2002; Almeida et al., 2002; Anazetti et al., 2003). Regarding to AAA biological importance, this compound proved to possess antibiotic (Addae-Mensah et al., 1992) and antibacterial (Peres et al., 1997) activities. Gastrointestinal effects in mice were also reported (Maciel et al., 2000). This terpenoid has shown no efficacy on both antitumoral (Grynberg et al., 1999) and gastric mucosa damage in rats, caused by ulcers induced by restraint - cold stress (Maciel et al., 2000).

In the course of our studies on pharmacological active substances from Croton cajucara, we describe in this present study the anti-inflammatory and antinociceptive effects related to the triterpene AAA and the diterpene-type 19-nor-clerodane CTN, additionally with an aqueous extract obtained from its stem bark.

\section{MATERIAL AND METHODS}

\section{Plant extracts, isolation and semi-synthesis}

The plant material was collected in Jacundá, PA (Amazon region of Brazil) and identified by Dr. Nelson A. Rosa. A voucher specimen has been deposited in the Herbarium of the Museu Paraense Emílio Goeldi (Belém-PA), under registration \# 247.

The compounds used in this study were obtained as previously described (Maciel et al., 1998a,b, 2003). Briefly, the powdered stem bark of Croton cajucara was extracted with hexane and then methanol by Soxhlet apparatus. This procedure furnished $471.8 \mathrm{~g}$ and 202.0 $\mathrm{g}$ of each extract. Isolation procedures yielded $4.5 \mathrm{~g}$ of
AAA and $37.2 \mathrm{~g}$ of DCTN. The hydrogenation of DCTN in $95 \%$ ethanol was carried out as previously described (Maciel et al., 2000). The semi-synthetic CTN-derivative was recrystallized twice with hexane-acetone and the identity of this compound was confirmed by comparison with chemical and spectroscopic methods of the isolated CTN (Maciel et al., 2000).

The water extract (AE) was prepared from ground shade-dried stem barks (500 g), extracted with distilled water $\left(70{ }^{\circ} \mathrm{C}, 30\right.$ minutes $)$, concentrated under vacuum and freeze-dried. This process furnished $25 \mathrm{~g}$ of water extract (yielding 5\%).

\section{Animals}

Male rats (Rattus norvegicus, albinus, Wistar) and male mice (Mus musculus, albinus, Swiss), specific pathogen free, weighing $150-200 \mathrm{~g}$ and $20-25 \mathrm{~g}$, respectively, were acquired from the Central Biotery of Universidade de Alfenas. The animals were kept in polyethylene boxes $(n=6)$, in a climatic environment $\left(23 \pm 2{ }^{\circ} \mathrm{C}\right)$, with air humidity control, in 12 hour/shifts with dark/light control. Food and water were given ad libitum at least seven days before the experiments. The animals were provided only with water ad libitum during the 12 hours before experimentation. This study was conducted according to internationally accepted principles of laboratory animal use (Porter, 1992; Zimmermann, 1983, 1986).

\section{Drugs}

The terpenoids CTN and AAA were administrated in $0.9 \%$ saline solution with Tween 80 $(5 \%)$ or DMSO $0.5 \%$. The doses used $(50 \mathrm{mg} / \mathrm{kg}$ of CTN and $50 \mathrm{mg} / \mathrm{kg}$ of AAA) were chosen according to previous studies (Perazzo et al., 1997; Carvalho et al., 1996). The polar extract AE was diluted in saline solution in a concentration to allow administration of constant volume orally $(300 \mathrm{mg} / \mathrm{kg}, 1.0 \mathrm{~mL})$.

\section{Determinations of aqueous extract ED $_{50}$}

Groups of mice $(\mathrm{n}=6)$ were treated orally with Croton cajucara aqueous extract (AE; 100, 300 or $1000 \mathrm{mg} / \mathrm{kg}$ ) or vehicle (water) 60 minutes before the injection of the stimulus $(1.0 \%$ acetic acid solution, i.p.). The writhing number was counted for 20 minutes, starting at the $5^{\text {th }}$ minute after the stimulus. $\mathrm{ED}_{50}$ was determined from dose-response curve drawn for the percentage of writhing inhibition as a function of the dose (Koster et al., 1959).

\section{Writhing test induced by acetic acid}

This test was done using the method described by Koster et al. (1959). Groups of mice $(n=6)$ were 
treated orally with CTN $(50 \mathrm{mg} / \mathrm{kg})$, AAA $(50 \mathrm{mg} / \mathrm{kg})$, $\mathrm{AE}(300 \mathrm{mg} / \mathrm{kg})$, indomethacin $(10 \mathrm{mg} / \mathrm{kg})$ or water $(0.5 \mathrm{~mL}) 30$ minutes before an $1.0 \%$ acetic acid solution injection $(0.25 \mathrm{~mL} / \mathrm{kg}$, i.p.). The number of muscular contractions was counted for 20 minutes, starting at the $5^{\text {th }}$ minute after the stimulus. During the experiment, each mouse was kept in individual boxes and results are presented as either cumulative number of writhes or percentage of inhibition of writhes comparatively to the control group.

\section{Carrageenin, dextran and histamine-induced paw edema in rats}

Groups of rats $(\mathrm{n}=6)$ were treated orally with CTN (50 mg/kg), AAA (50 mg/kg), AE (300 mg/kg), indomethacin $(10 \mathrm{mg} / \mathrm{kg})$, cyproheptadine $(10 \mathrm{mg} / \mathrm{kg})$ or $5 \%$ Tween 80 [0.9\% saline solution (control, $1.0 \mathrm{~mL}$ )]. Thirty minutes later, carrageenin $(1000 \mu \mathrm{g}, 0.1 \mathrm{~mL})$, dextran $(50 \mu \mathrm{g}, 0.1 \mathrm{~mL})$ or histamine $(50 \mu \mathrm{g}, 0.1 \mathrm{~mL})$ was injected into the sub-plantar region of the left hind paw of the animals. The right paw was injected with $0.1 \mathrm{~mL}$ of $0.9 \%$ saline solution. The volume of each paw was determined using a plethysmometer (model 7140, Ugo Basile, Italy) as described by Ferreira (1979). The results were expressed by the difference between the volume of right and left paws.

\section{Statistical analysis}

The statistical analyses were done using Analysis of Variance (ANOVA) followed by the TukeyKramer multiple comparison test (Sokal; Rohlf, 1995). Results with $\mathrm{p}<0.05$ were considered to be significant. Data are expressed as mean \pm S.D.

\section{RESULTS AND DISCUSSION}

The study of ethnopharmacological uses, phytochemistry and pharmacology of Croton cajucara represents a successfully combination of efforts to discover new compounds related to some properties of this medicinal specie. As a continuing research of this study, two terpenoids (CTN and AAA; Figure 1) as well as the traditional used tea (comparative to an aqueous extract of the stem bark of Croton cajucara) were submitted to a screening in order to investigate its anti-inflammatory activity.

The acetic acid-induced writhing test has been used for pre-clinical evaluation of analgesic potency of novel anti-inflammatory drugs (Loux et al., 1978) and involves the synthesis of prostaglandins, which are the main nociceptive mediators in this model (Deraedt et al., 1980). Oral administration of aqueous extract (AE) produced dose-response reduction of the number of writhes, as showed in Table 1. The maximal inhibition of antinociceptive response was $68.7 \%$, obtained with

$1000 \mathrm{mg} / \mathrm{kg}$ and the $\mathrm{ED}_{50}$ determined as $305 \mathrm{mg} / \mathrm{kg}$. The oral administration of CTN and AAA $(50 \mathrm{mg} / \mathrm{kg})$ inhibited the number of muscular contractions in $46.5 \%$ and $60.4 \%$, respectively (Figure 2). This effect was not so pronounced with that showed by the group treated with indomethacin $(80.2 \%)$.

Administration of CTN and AAA significantly inhibited carrageenin-induced edema formation in all time intervals (Figure 3). The great inhibition was at the first hour for AAA (47.7\%) and in the second hour for CTN (54.4\%). Indomethacin, the standard drug used, inhibited the edema formation by $36.7 \%$, at the first hour after carrageenin injection. Carrageenin-induced edema is one of the first models of inflammation used to investigate new anti-inflammatory drugs and is characterized by an initial phase, mediated by histamine and serotonin, and by a later phase, when the mediators are arachidonic acid metabolites producing edema after mobilization of neutrophils (Vinegar et al., 1987; Ferrándiz; Alcaraz, 1991). CTN and AAA were effective in the two phases of the process and this effect was evidenced by results obtained in other models.

Similar to the results obtained with DCTN (Carvalho et al., 1996), CTN and AAA did not present analgesic activity in either hot-plate and tail-flick tests (data not shown).

Dextran-induced edema is also an acute experimental model of inflammation that induces an anaphylactoid reaction, characterized by a slow developing edema, starting in about 60 - $90 \mathrm{~min}$. after dextran injection. It triggers the release of kinins, lipoxygenase derived products and histamine and serotonin from mast cells (Ankier; Neat, 1972; Nishida; Tomizawa, 1980; Van Wauwe; Goossens, 1989).

The terpenoids CTN and AAA showed a significant inhibition 1.5 and 3.5 hours after dextran injection (Figure 4), with the best inhibition at 1.5 hours $(31.9 \%$ for CTN and $28.5 \%$ for AAA). However, treatment with cyproheptadine $(10 \mathrm{mg} / \mathrm{kg})$, a serotonin and histamine $\mathrm{H}_{1}$ antagonist, was clearly more effective in the two time intervals. Both compounds significantly inhibited the histamine-induced edema (43.2\% for CTN and $40.5 \%$ for AAA) and this effect was quite similar with that observed with cyproheptadine (Figure 5).

\section{CONCLUSION}

The limitation of the use of some antiinflammatory and analgesic agents is the risk to produce gastric irritation. The combination of anti-inflammatory and antiulcerogenic effects in the same compound is very favorable, but unusual. Nevertheless some natural products exhibit both properties (Sertié, 1991). Some of our results in the experimental model of gastric ulcers, used to evaluate gastric ulceration in rodents showed that DCTN and CTN in the doses of $100 \mathrm{mg} / \mathrm{kg}$ had protected against ulcers and mucosal damage induced

Rev. Bras. Farmacogn. 
by cold restraint-induced stress (Maciel et al., 2000). However, AAA was not effective. DCTN and CTN have also demonstrated antiulcerogenic effect in other gastric ulcer models (Hiruma-Lima et al., 2002). Advances in Croton cajucara research with DCTN proved that it has not shown nor genotoxicity neither cytotoxicity to bone marrow cells in mice (Agner et al., 1999, 2001), representing that the anti-inflammatory activity of these compounds could be useful in the general bioavailability of these diterpene-type clerodanes.

The results showed in the present study demonstrated that CTN, AAA and AE have antinociceptive activity when assessed in a model of peripheral nociception such as acetic acid-induced abdominal constriction. Furthermore, when investigated in thermal algesiometric test (tail-flick), considered as a selective test for opioid-like analgesic compound (Janssen et al., 1963), AE did not show antinociceptive effect.

Additionally, the present study reinforces the chemical results with the bioactive DCTN and the improvement obtained shows that CTN and AAA together with DCTN, are some of the compounds responsible for anti-inflammatory and antinociceptive activities observed for Croton cajucara. Those terpenoids were found to be part of the traditional tea preparation of this specie, showing to have antiinflammatory and antinociceptive activities. Allied to the fact that the diterpenes DCTN and CTN had shown an antiulcerogenic effect and no gastric damage, the use of such compounds could be advantageous, which extending and supporting the popular medicine and folkloric uses of Croton cajucara in the Amazon region of Brazil.

\section{ACKNOWLEDGMENTS}

The authors gratefully acknowledge technical assistance of Luis Eduardo dos Santos (FCF-UNESP) and also PRODOC/CAPES program.<smiles>CC(=O)OC1CC[C@]2(C)[C@@H]3CC[C@H]4C5=CC[C@]6(C(=O)O)CCC(C)(C)CC6[C@]5(C)CC[C@]4(C)[C@H]3[C@@]2(C)C1</smiles>

AAA<smiles>CC1=CC(=O)C[C@H]2[C@@H]1CC[C@@H](C)[C@]21C[C@H](c2ccoc2)OC1=O</smiles>

DCTN<smiles>C[C@H]1CC[C@H](C)[C@]2(C[C@H](c3ccoc3)OC2=O)[C@@H]2[C@H]1CC(=O)C[C@H]2C</smiles>

CTN

Figure 1. Molecular structure of acetyl aleuritolic acid (AAA), trans-crotonin (CTN) and trans-dehydrocrotonin (DCTN). 
Table 1. Effect of oral aqueous (AE) extract of Croton cajucara on acetic acid-induced abdominal constrictions in mice.

\begin{tabular}{lll}
\hline Treatment & Dose $\mathrm{mg} / \mathrm{kg}$ & $\begin{array}{l}\text { Number of abdominal } \\
\text { constrictions }\end{array}$ \\
\hline Saline solution (control) & - & $61.0 \pm 5.8$ \\
Aqueous extract & 100 & $40.2 \pm 3.9 *$ \\
& 300 & $33.3 \pm 5.3 * *$ \\
& 1000 & $19.1 \pm 6.8 * *$ \\
\hline
\end{tabular}

Each value represents the mean \pm S.D $(\mathrm{n}=6)$. Significantly different from control group $\left({ }^{*} p<0.05\right.$ and $* * p<0.001$, TukeyKramer multiple comparison test).

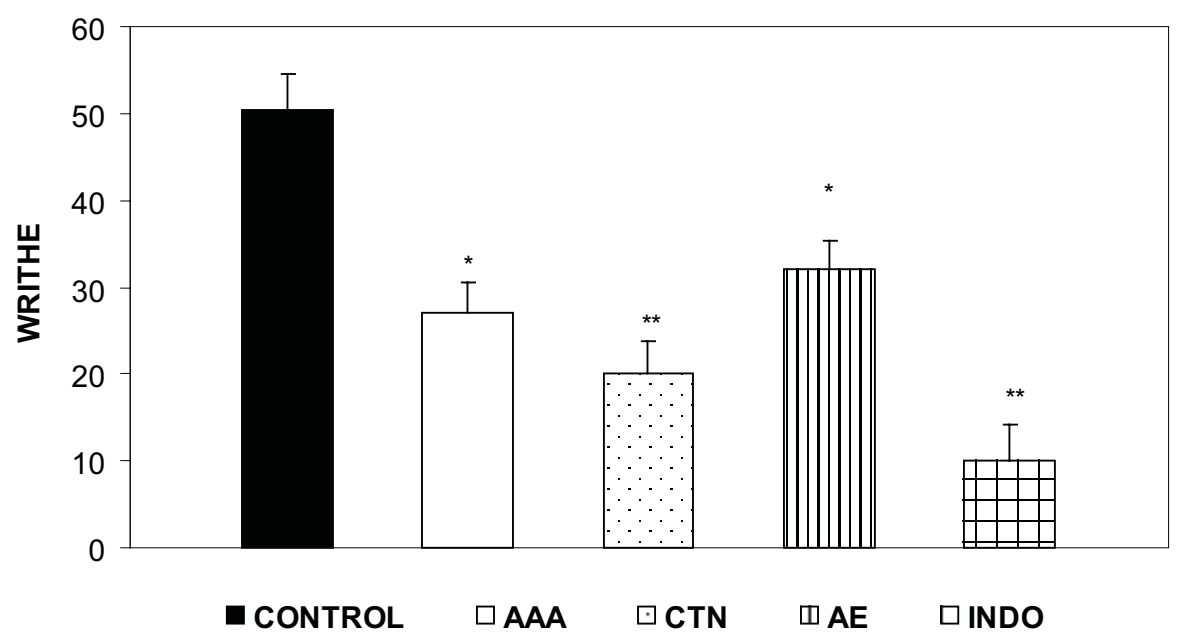

Figure 2. Effect of oral administration of AAA ( $50 \mathrm{mg} / \mathrm{kg}), \mathrm{CTN}(50 \mathrm{mg} / \mathrm{kg}), \mathrm{AE}(300 \mathrm{mg} / \mathrm{kg})$, and indomethacin $(10 \mathrm{mg} / \mathrm{kg}) \mathrm{on}$ the writhing test induced by intraperitoneal acetic acid injection $(1.0 \%, 0.25 \mathrm{~mL} /$ animal $)$ in mice. The results are expressed as mean \pm SD obtained $(\mathrm{n}=6)$. Significantly different from the control group $\left({ }^{*} p<0.05\right.$ and ${ }^{* *} p<0.01$, Tukey- Kramer multiple comparison test).

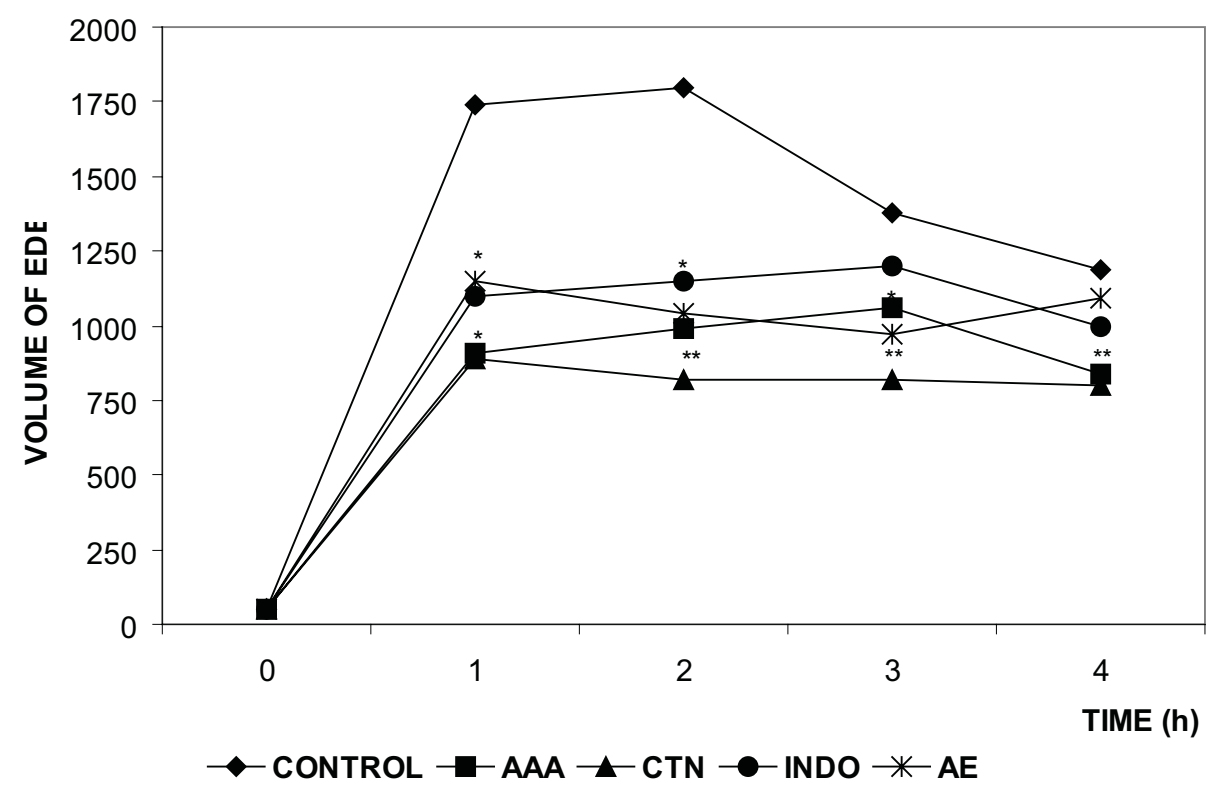

Figure 3. Effect of oral administration of AAA $(50 \mathrm{mg} / \mathrm{kg}), \mathrm{CTN}(50 \mathrm{mg} / \mathrm{kg}), \mathrm{AE}(300 \mathrm{mg} / \mathrm{kg})$ and indomethacin $(10 \mathrm{mg} / \mathrm{kg})$ on the carrageenin-induced paw edema $(1000 \mathrm{mg} / \mathrm{paw})$ over a four-hour period in rats. The results are expressed as mean $\pm \operatorname{SD}(\mathrm{n}=6)$. Significantly different from the control group $\left({ }^{*} p<0.05\right.$ and ${ }^{*} p<0.01$, Tukey- Kramer multiple comparison test). 


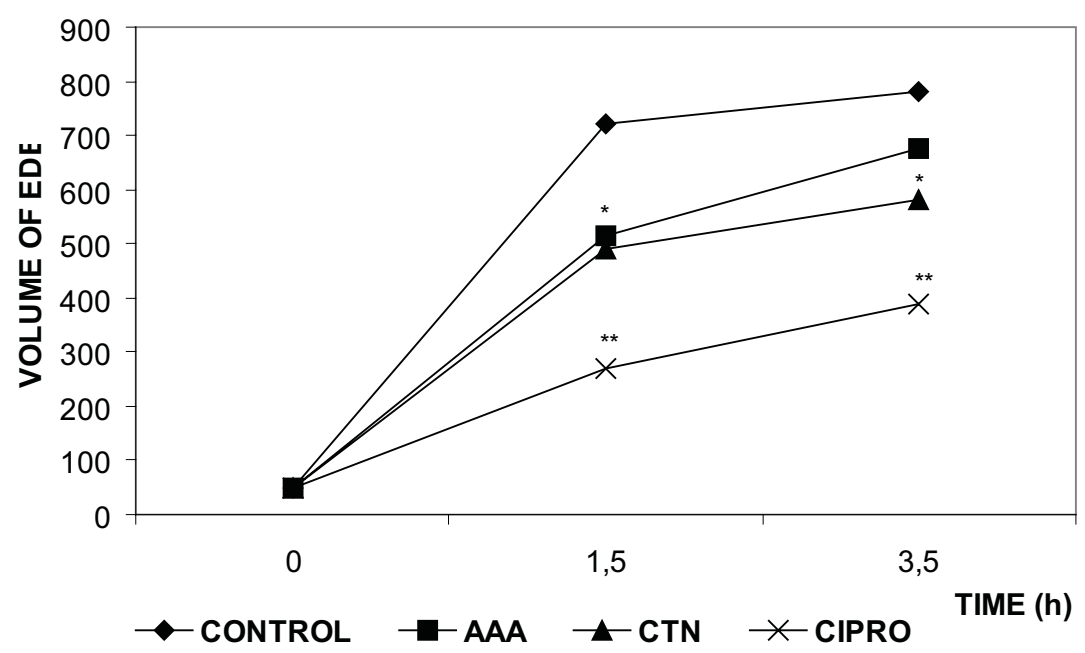

Figure 4. Effect of oral administration of AAA (50 mg/kg), CTN (50 mg/kg) and cyproheptadine (10 mg/kg) on dextran-induced paw edema $(50 \mathrm{mg} / \mathrm{paw})$ over a 3.5 hour period in rats. The results are expressed as mean $\pm \mathrm{SD}(\mathrm{n}=6)$. Significantly different from the control group $\left({ }^{*} p<0.05\right.$ and ${ }^{* *} p<0.01$, Tukey- Kramer multiple comparison test).

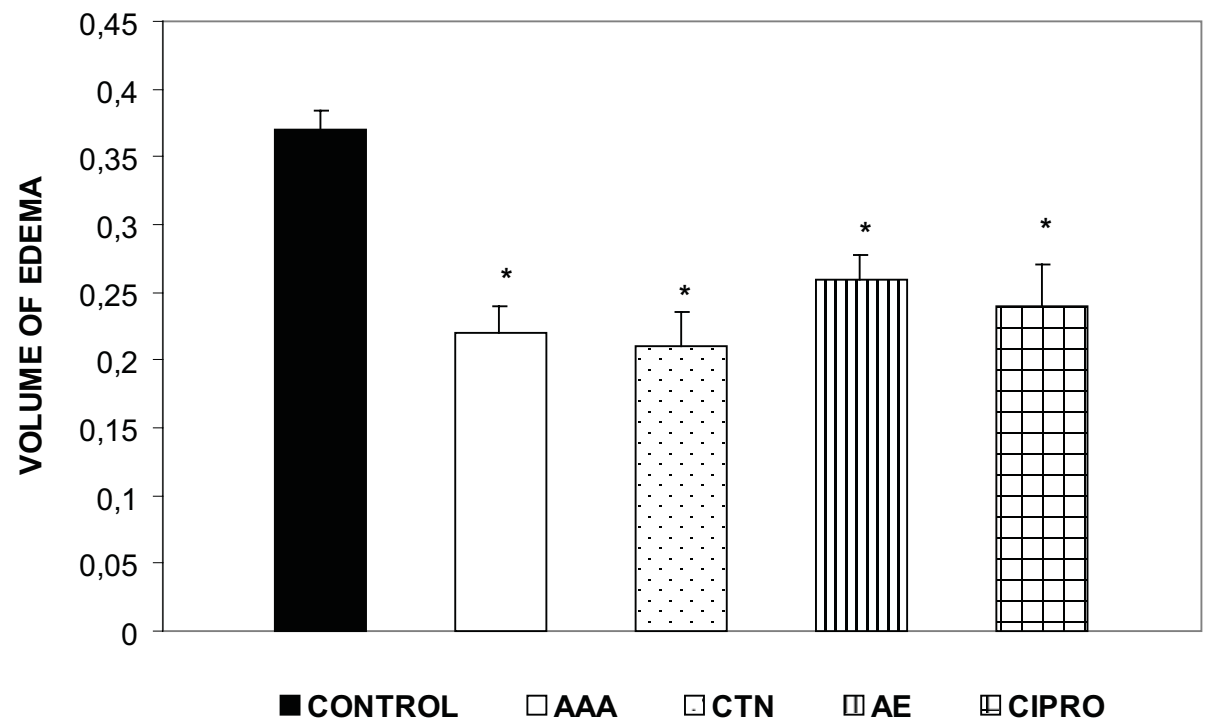

Figure 5. Effect of oral administration of AAA $(50 \mathrm{mg} / \mathrm{kg})$ CTN $(50 \mathrm{mg} / \mathrm{kg})$, AE (300 mg/kg), and cyproheptadine $(10 \mathrm{mg} / \mathrm{kg})$ on histamine-induced paw edema $(1000 \mathrm{mg} / \mathrm{paw})$ over a 90 minutes period in rats. The results are expressed as mean \pm SD $(\mathrm{n}=6)$. Significantly different from the control group $\left({ }^{*} p<0.05\right.$ and Tukey- Kramer multiple comparison test).

\section{REFERENCES}

Addae-Mensah I, Achenbach H, Thoithi GN, Waibel R, Mwangi JW 1992. Epoxychiromodine and other constituents of Croton megalocarpus. Phytochemistry 31: 2055-2058.

Agner AR, Maciel MAM, Pinto AC, Pamplona GRS, Cólus IMS 1999. Investigation of genotoxic activity of trans-dehydrocrotonin, a clerodane diterpene from Croton cajucara. Teratogen Carcin Mut 19: 377-384.
Agner AR, Maciel MAM, Pinto AC, Cólus ISM 2001. Antigenotoxicity of trans-dehydrocrotonin, a clerodane diterpene from Croton cajucara. Planta Med 67: 815-819.

Almeida ABA, Miotto AM, Nunes DS, Spadari-Bratifisch RC, Souza-Brito ARM 2002. Mechanism of antiulcerogenic activity of semi-synthetic crotonin obtained from Croton cajucara Benth. Rev Bras Farmacogn 12(Supl. 1): 105-110.

Anazetti MC, Melo PS, Duran N, Haun M 2003. Comparative cytotoxicity of dimethylamide-crotonin in the promyelocytic leukemia cell line (HL60) and human 
peripheral blood mononuclear cells. Toxicol 188: 261-274.

Ankier SI, Neat ML 1972. Some studies on acute inflammation induced by dextran in the mouse. Int Arch Allergy Appl Immunol 42: 264-277.

Barbosa-Filho JM, Vasconcelos THC, Alencar AA, Batista LM, Oliveira RAG, Guedes DN, Falcão HS, Moura MD, Diniz MFFM, Modesto-Filho J 2005. Plants and their active constituents from South, Central, and North America with hypoglycemic activity. Rev Bras Farmacogn 15: 392-413.

Carvalho JCT, Silva MFC, Maciel MAM, Pinto AC, Nunes DS, Lima RM, Bastos JK, Sarti SJ 1996. Investigation of anti-inflammatory and antinociceptive activities prototype of trans-dehydrocrotonin, a 19-norclerodane diterpene from Croton cajucara. Part 1. Planta Med 62: 402-404.

Costa MP, Magalhães NSS, Gomes FES, Maciel MAM 2007. Uma revisão das atividades biológicas da transdesidrocrotonina, um produto natural obtido de Croton cajucara. Rev Bras Farmacogn 17: 275-286.

Deraedt R, Jouquey S, Delevallee F, Flauhaut M 1980. Release of prostaglandins $\mathrm{E}$ and $\mathrm{F}$ in an algogenic reaction and its inhibition. Eur J Pharmacol 61: 17-24.

Di Stasi LC, Santos EMG, Santos CM, Hiruma CA 1989. Plantas Medicinais da Amazônia. Editora UNESP, São Paulo, Brazil.

Di Stasi LC, Hiruma CA, Guimarães EM, Santos CM 1994. Medicinal plants popularly used in Brazilian Amazon. Fitoterapia 65: 529-540.

Farias RAF, Neto MFO, Viana GSB, Rao VSN 1996. Effects of Croton cajucara extract on serum lipids of rats fed a high fat diet. Phytother Res 10: 697-699.

Farias RAF, Rao VSN, Viana GSB, Silveira ER, Maciel MAM, Pinto AC 1997. Hypoglycemic effect of trans-dehydrocrotonin, a nor-clerodane diterpene from Croton cajucara. Planta Med 66: 558-560.

Ferrándiz ML, Alcaraz MJ 1991. Antiinflammatory activity and inhibition of arachidonic acid metabolism by flavonoids. Agents Actions 32: 283-288.

Ferreira SH 1979. A new method for measuring variations of rats paw volumes. J Pharm Pharmacol 31: 648.

Grynberg NF, Echevarria A, Lima JE, Pamplona SGSR, Pinto AC, Maciel MAM 1999. Anti-tumor activity of two 19-nor-clerodane diterpenes: trans-dehydrocrotonin and trans-crotonin from Croton cajucara. Planta Med 65: 687-689.

Hiruma-Lima CA, Toma W, Gracioso JS, Almeira AB, Batista LM, Magri L, de Paula AC, Soares FR, Nunes DS, Brito ARS 2002. Natural trans-crotonin: the antiulcerogenic effect of another diterpene isolated from the bark of Croton cajucara Benth. Biol Pharm Bull 25: 452-456.

Janssen PAJ, Niemegeers CJE, Dony JGH 1963. The inhibitory effect of fentanyl and other morphine-like analgesics on the warm water induced tail withdrawal reflex in rats. Arzneimittel-Forsch Drug Res 6: 502-507.

Koster R, Anderson M, DeBeer EJ 1959. Acetic acid analgesic screening. Federation Proceedings 18: 418- 420.

Loux JJ, Smith S, Salem H 1978. Comparative analgetic testing of various compounds in mice using writhing techniques. Arzneimittel-Forsch 28: 1644-1647.

Luna-Costa AM, Silva JCR, Campos AR, Rao VSN, Maciel
MAM, Pinto AC 1999. Antioestrogenic effect of trans-dehydrocrotonin, a nor-clerodane diterpene from Croton cajucara Benth. in rats. Phytother Res 13: 689-691.

Maciel MAM, Pinto AC, Brabo SN, Silva MN 1998a. Terpenoids from Croton cajucara. Phytochemistry 49: 823-828.

Maciel MAM, Pinto AC, Brabo SN, Arruda AC 1998b. Estudo da variação dos teores de terpenóides bioativos isolados das cascas do caule de Croton cajucara, nativos e cultivados no estado do Pará. Rev Univ Rural, Ser Ciências Exatas e da Terra 18/20: 17-34.

Maciel MAM, Pinto ACP, Arruda AC, Pamplona SGSR, Vanderlinde FA, Lapa AJ, Cólus IMS, Echevarria A, Grynberg NF, Farias RAF, Luna-Costa AM, Rao VSN 2000. Ethnopharmacology, phytochemistry and pharmacology: a successful combination in the study of Croton cajucaran. J Ethnopharmacol 70: 41-55.

Maciel MAM, Pinto AC, Kaiser CR 2003. NMR and structure review of some natural furoclerodanes. Magn Reson Chem 41: 278-282.

Martins JEC 1989. Plantas medicinais de uso na Amazônia. Centros de estudos jurídicos do Pará, Belém, Brazil.

Nishida S, Tomizawa S 1980. Effects of compound $48 / 80$ on dextran-induced paw edema and histamine content of inflammatory exudate. Biochem Pharmacol 29: 1073-1075.

Perazzo FF, Rodrigues M, Carvalho JCT, Maciel MAM, Pinto AC, Arruda AC, Pamplona SGSR, Antoniássi NC 1997. Mendoza: II WOCMAP, 378.

Peres MT, Monache FD, Cruz AB, Pizzolatti MG, Yunes RA 1997. Chemicalcompositionandantimicrobialactivity of Croton urucurana Baillon. J Ethnopharmacol 56: 223-226.

Porter DG 1992. Ethical scores for animal experiments. Nature 356: 101-102.

Sertié JAA, Basile S, Panizza S, Oshiro TT, Azzolini CP, Penna SC 1991. Pharmacological assay of Cordia verbenacea III: Oral and topical anti-inflammatory activity and gastrotoxicity of a crude leaf extract. $J$ Ethnopharmacol 31: 239-247.

Silva RM, Santos FA, Maciel MAM, Pinto AC, Rao VS 2001. Effect of trans-dehydrocrotonin, a 19-nor-clerodane diterpene from Croton cajucara on experimental hypertriglyceridaemia and hypercholesterolaemis induced by Triton WR 1339 (tyloxapol) in mice. Planta Med 67: 763-765.

Sokal RR, Rohlf FJ 1995. Biometry, New York: WH Freeman, USA.

Souza MAA, Souza SR, Veiga Jr VF, Cortez JKPC, Leal RS, Dantas TNC, Maciel MAM 2006. Composição química do óleo fixo de Croton cajucara e determinação das suas propriedades fungicidas. Rev Bras Farmacogn 16(Supl.): 599-610.

Van Den Berg ME 1993. Plantas medicinais na AmazôniaContribuição ao seu conhecimento sistemático. $2^{\mathrm{a}}$ Ed. Belém: Museu Paraense Emílio Goeldi, CNPqMCT (Coleção Adolpho Ducke), Brazil.

Van Wauwe JP, Goossens JG 1989. Arabinogalactanand dextran-induced ear inflammation in mice: differential inhibition by $\mathrm{H} 1$-antihistamines, 5-HTserotonin antagonists and lipoxygenase blockers. Agents Actions 28: 78-82. 
Vinegar R, Truax JF, Selph JL, Johnston PR, Venable AL, Mckenzie KK 1987. Pathway to carrageenan-induced inflammation in the hind limb of the rat. Federation Proceedings 46: 118-126.

Zimmermann M 1983. Ethical guidelines for investigations of experimental pain in conscious animals. Pain 16: 109-110.

Zimmermann M 1986. Ethical considerations in relation to pain in animal experimentation. Acta Physiol Scand 554 (Suppl.): 221-233. 